\title{
Interaction Interface between 5-HT3A serotonin receptor and RIC-3 chaperone
}

\author{
Hoa Quynh Do ${ }^{1}$, Michaela Jansen ${ }^{1 *}$ \\ ${ }^{1}$ Department of Cell Physiology and Molecular Biophysics and Center for Membrane Protein \\ Research, School of Medicine, Texas Tech University Health Sciences Center, $36014^{\text {th }}$ street, \\ Lubbock, TX 79430, USA \\ *Corresponding author \\ Email: michaela.jansen@ttuhsc.edu
}

\section{Running title:}

5- $\mathrm{HT}_{3 \mathrm{~A}}$ interaction interface with RIC-3

\section{Keywords}

neurotransmitter receptor, pentameric ligand-gated ion channel, ion channel, serotonin receptor type 3, 5-HT3A, nicotinic acetylcholine receptors, resistance to inhibitors of cholinesterase type 3, biosynthesis, chaperone, protein-protein interaction, pull-down assay, hotspot, RIC-3.

\begin{abstract}
Serotonin or 5-hydroxytryptamine receptors type $3\left(5-\mathrm{HT}_{3}\right)$ belong to the family of pentameric ligand-gated ion channels (pLGICs), which also includes other neurotransmitter-gated ion channels such as nicotinic acetylcholine receptors, $\gamma$-amino butyric acid A receptors, and glycine receptors. pLGICs have been long-standing clinical targets for treating psychiatric disorders such as anxiety, schizophrenia, addiction, and neurological diseases like Alzheimer's and Parkinson's disease. Due to the highly-homologous structures of pLGICs' extracellular and transmembrane domains, clinical trials for drug candidates targeting these domains have been largely hampered by undesired effects mediated by off-subunit modulation. With the present study, we explore the interaction interface of the 5- $\mathrm{HT}_{3 \mathrm{~A}}$ intracellular domain (ICD) with the resistance to inhibitors of choline esterase (RIC-3) chaperone. Protein-protein interactions are attractive and successful targets for contemporary drug development. Previously, we have shown that RIC-3 physically interacts with 5- $\mathrm{HT}_{3 \mathrm{~A}}$ subunits, and we identified the L1-MX fragment of the ICD fused to maltose-binding protein as sufficient for interaction. For the present study, synthetic L1-MXbased fragments and Ala-scanning were used to probe binding to RIC-3 using a pull-down assay. In complementary studies with full-length 5- $\mathrm{HT}_{3 \mathrm{~A}}$ subunits, we investigated the impact of these substitutions on modulation of functional surface expression by RIC-3 using two-electrode
\end{abstract}


voltage-clamp recording after expression in Xenopus laevis oocytes. Our data demonstrate that the 5- $\mathrm{HT}_{3 \mathrm{~A}}-\mathrm{MX}$ segment contains the interaction interface, and that residues W347, R349, and L353 are critical for the interaction with RIC-3.

\section{Abbreviations:}

The serotonin receptor type $3\left(5-\mathrm{HT}_{3}\right)$, nicotinic acetylcholine receptor (nAChR), pentameric ligand-gated ion channels (pLGICs), protein-protein interaction (PPI)

\section{Introduction}

Serotonin or 5-hydroxytryptamine type 3 receptors $\left(5-\mathrm{HT}_{3}\right)$ belong to the family of pentameric ligand-gated ion channels (pLGICs), which also includes other neurotransmitter-gated ion channels such as nicotinic acetylcholine receptors (nAChR), $\gamma$-amino butyric acid A receptors $\left(\mathrm{GABA}_{\mathrm{A}} \mathrm{R}\right)$, and glycine receptors (GlyR) ${ }^{1,2}$. Gating of 5-HT3 channels by the endogenous agonist serotonin results in permeation by cations and signal transduction in the nervous system 3-10. pLGICs' involvement in brain-gut signaling circuitry and other non-serotonergic synaptic activities render these receptors effective therapeutic targets for the treatment of conditions such as irritable bowel syndrome, chemotherapy-induced vomiting, inflammation, and psychiatric disorders ${ }^{1,11-16}$

5- $\mathrm{HT}_{3}$ receptors assemble either into homopentamers from 5- $\mathrm{HT}_{3 \mathrm{~A}}$ subunits or heteropentamers by combining $5-\mathrm{HT}_{3 \mathrm{~A}}$ subunits with other subunits (B through $\left.\mathrm{E}\right)^{17-19} \cdot 5-\mathrm{HT}_{3 \mathrm{~A}}$ subunits share their molecular structure with the pLGICs family. Each homologous subunit comprises three domains: an extracellular N-terminal domain housing agonist-binding sites (ECD), a transmembrane domain enabling cations to cross the plasma membrane (TMD), and an intracellular domain playing critical roles in channel conductance and functional expression ${ }^{20-22}$ (ICD). The transmembrane domain consists of four $\alpha$-helical transmembrane-spanning segments called M1, M2, M3, and M4 (Figure 1A). M3 and M4 are connected by a 115-amino acid segment that makes up the main part of the intracellular domain (ICD). Structures of the 5-HT $3 \mathrm{~A}$ receptor ECD, TMD and parts of the ICD was solved by X-ray crystallography and cryo-EM, demonstrating that the ICD consists of a short loop (L1) that connects M3 with a short helical fragment (MX), and a large unresolved loop (L2) leading into the MA-M4 helix (Fig.1) ${ }^{21-24}$. Within the pLGIC superfamily of more than 40 subunits in humans, the M3-M4 cytoplasmic loops or ICDs exhibit significant diversity in length, amino acid composition, and function. This domain has been considered largely disordered ${ }^{21,22,25-28}$. ICDs regulate gating and ionic conductance $^{29-31}$, as well as mediate channel assembly and trafficking via interactions with intracellular proteins ${ }^{23,32-34}$. Of these intracellular proteins, an endoplasmic reticulum-resident chaperone, Resistance to Inhibitors of Cholinesterase type 3, or RIC-3, functions to assist cell 
surface expression or functional expression of serotonin type 3A and nicotinic acetylcholine receptors ${ }^{30,35-45}$.

The extracellular domains (ECD) and transmembrane domains (TMD) of pentameric neurotransmitter-gate ion channels are long-standing clinical targets for treatments of psychiatric and neurological disorders. The highly homologous structure of ECDs and TMDs, respectively, led to interactions of drug candidates with off-target subunits, and consequently caused the discontinuation of many late clinical trials by Pfizer, Astra Zeneca, GlaxoSmithKline, BristolMayer Squibb $21,22,26-28,46$.

To search for an effective approach to regulate diverse functional properties of pLGICs, we have explored the interaction of the ICD of the 5- $\mathrm{HT}_{3 \mathrm{~A}}$ receptor and RIC-3 chaperone. Protein-protein interactions have been successfully employed in drug development ${ }^{47-55}$. Our previous studies on this interaction indicate a direct interaction between the ICD and RIC-3 that is mediated via the L1-MX segment of the ICD ${ }^{50,52}$. However, insights into specific residues of the interaction interface or the molecular binding motif between $\mathrm{RIC}-3$ and $5-\mathrm{HT}_{3 \mathrm{~A}}$ receptors remain elusive. A refined structural understanding of this interaction is expected to provide the basis for the structure-based design of new chemical entities (NCEs) interfering with this interaction and thus for the development of therapeutics for neurological and psychiatric disorders.

With the present study, using alanine-scanning mutagenesis, a protein-protein pull-down assay, and two-electrode voltage-clamp recordings, we provide evidence for the physical interaction between the 5-HT $\mathrm{HA}_{3 \mathrm{~A}} \mathrm{~L} 1-\mathrm{MX}$ segment, as compared to the MBP-5-HT ${ }_{3 \mathrm{~A}} \mathrm{~L} 1-\mathrm{MX}$ segment previously used $^{50-52}$, and RIC-3 protein. We further demonstrate that MX contains the interaction interface or sequence determinant for the interaction between the 5- $\mathrm{HT}_{3 \mathrm{~A}}$ subunit and RIC-3. We identify a motif of three conserved residues, W347, R349, and L353 in MX, which is essential for the interaction with RIC-3. These residues are conserved across species and family members of pLGICs. Finally, we propose that the $5-\mathrm{HT}_{3 \mathrm{~A}}$ subunit harbors a second binding site, also on an $\alpha$-helical surface, for RIC-3, with the first site located to MX and the second site at the transition between the MA and M4 helices. In the $5-\mathrm{HT}_{3 \mathrm{~A}}$ structures these motives are in close proximity at the interface between the lipid bilayer and cytosol.

\section{Materials and Methods}

\section{Mutagenesis}

Single amino acid substitutions in the serotonin type 3A (5-HT $3 \mathrm{~A})$ subunit, W347A, R349A, and L353A, and a triple substitution W347A, R349A, and L353A (or WRLAAA) were generated using appropriate primers and the QuikChange II XL Site-Directed Mutagenesis kit (Agilent Technologies) and were confirmed by DNA sequencing. The forward primers for the individual substitutions W347A, R349A, and L353A were 5'- 
CGGCCAGTACCTGACGCACTGAGGCACCTGGTC-3', 5'-CAGTACCT-

GACTGGCTGGCACACCTGGTCCTAGACAG-3', and 5'-CTGAGGCACCTGGTCGCAGACAGAATAGCCTGG-3', respectively. The forward primer for the triple substitution WRLAAA

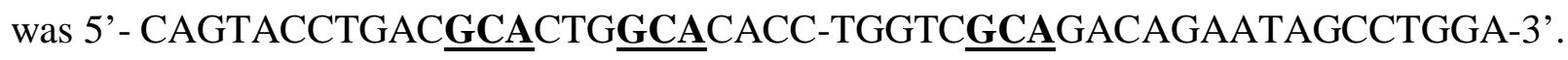
All DNA sequences were confirmed by Genewiz/Azenta.

\section{Complementary RNA (cRNA) production and oocyte injection}

Expression plasmid vectors, pGEMHE19 and pXOON, carrying the human RIC3 sequence (GenBank: NM_001206671.2) and mouse 5-HT 3 A sequence (GenBank: AAT37716.1) with V5 epitope tag (GKPIPNPLLGLDSTQ) were generously provided by Dr. Millet Treinin (Hebrew University, Israel) and Dr. Myles Akabas (Albert Einstein College of Medicine, New York), respectively. Expression plasmid vectors containing substitutions of the mouse $5-\mathrm{HT}_{3 \mathrm{~A}}$ sequence were generated as described in the previous section.

The plasmid vector, $30 \mu \mathrm{g}$ each, was linearized for 18 hours at $37^{\circ} \mathrm{C}$ in a $250 \mu \mathrm{l}$ reaction containing restriction enzyme NheI and CutSmart buffer (New England Biolabs). The linear DNA plasmid was next used to produce complementary RNA (cRNA) of RIC-3 and 5-HT 3 A wild type and engineered receptors. This in vitro transcription process was performed by employing the mMESSAGE mMACHINE T7 Kit (Ambion by Life Technologies). The cRNA was then purified using the MEGAclear kit (Ambion by Life Technologies), dissolved in nuclease-free water, and stored at $-80^{\circ} \mathrm{C}$ until use.

\section{Expression of proteins in Xenopus laevis oocytes}

Defolliculated Xenopus laevis oocytes were purchased from Ecocyte Bioscience US LLC (Austin, TX). Oocytes were transferred to standard oocyte saline (SOS) medium (100 $\mathrm{mM} \mathrm{NaCl}$, $2 \mathrm{mM} \mathrm{KCl}, 1 \mathrm{mM} \mathrm{MgCl}$, $1.8 \mathrm{mM} \mathrm{CaCl}_{2}, 5 \mathrm{mM} \mathrm{HEPES}$; $\mathrm{pH}$ 7.5) supplemented with 1x antibiotic-antimycotic (ThermoFisher Scientific/Gibco Cat. \# 15240-062) and 5\% horse serum (Sigma-Aldrich, St. Louis, MO, USA). Oocytes were injected on the same day of the delivery. To express RIC-3, $10 \mathrm{ng}$ of cRNA (50 $\mu \mathrm{l}$ at $200 \mathrm{ng} / \mu \mathrm{l} \mathrm{cRNA})$ or $50 \mu \mathrm{l}$ of sterile water as control were injected into each oocyte; the oocytes were then incubated at $15^{\circ} \mathrm{C}$ for $65-68$ hours before being harvested for plasma membrane isolation. To co-express wild type (wt) or engineered

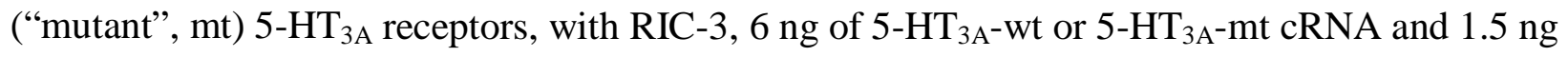
of RIC-3 cRNA were injected into each oocyte, respectively. Oocytes injected with 5- $\mathrm{HT}_{3 \mathrm{~A}}-\mathrm{wt}$ or $5-\mathrm{HT}_{3 \mathrm{~A}}-\mathrm{mt} \mathrm{cRNA}$ alone were used as controls. After the injection, the oocytes were incubated at 
$15^{\circ} \mathrm{C}$ for 3 days before they were used for two-electrode voltage-clamp (TEVC) recordings. SOS medium was replaced 12 hours after the injection and subsequently every 24 hours.

\section{Isolation of oocyte plasma membrane and solubilization of RIC3}

To isolate oocyte plasma membranes, oocytes were homogenized using a glass Teflon homogenizer and lysis buffer (25 mM MOPS, $1 \mathrm{mM} \mathrm{EDTA,} 0.02 \% \mathrm{NaN}_{3}$; $\mathrm{pH} 7.5$ ) supplemented with protease inhibitor cocktail III (Research Products International, Mt. Prospect, IL), $10 \mu l$ protease per $1 \mathrm{ml}$ lysis buffer, at a ratio of $20 \mu \mathrm{l}$ lysis buffer/ oocyte. The homogenization was performed by hand until no particles (dark granules) were visible. The homogenized oocytes were then centrifuge at $1,000 \square \times \square \mathrm{g}, 4^{\circ} \mathrm{C}$ for 10 minutes to remove cell debris. Next, the supernatant was transferred to a clean centrifuge tube, while the pellet was resuspended with another $20 \mu 1$ lysis buffer per oocyte. And the centrifugation was repeated. The second supernatant was combined with the first one, and subsequently, this mixture was spun at $200,000 \square \times \square \mathrm{g}, 4{ }^{\circ} \mathrm{C}$ for 45 minutes to obtain oocyte plasma membranes. After the ultracentrifugation, the membrane pellet was resuspended and washed with lysis buffer containing $1 \mathrm{M} \mathrm{NaCl}$ at a ratio of $20 \mu \mathrm{l}$ buffer per oocyte. This mixture was then spun at $200,000 \square \mathrm{x} \square \mathrm{g}, 4^{\circ} \mathrm{C}$ for 45 minutes to collect the membrane pellet. The resulting pellet was further resuspended and washed in lysis buffer containing $1 \mathrm{M} \mathrm{NaCl}$ and $2 \mathrm{mM} \mathrm{MgCl}_{2}$ at a ratio of $20 \mu \mathrm{l}$ buffer per oocyte and pelleted down again at 200,000 $\square \times \square \mathrm{g}, 4{ }^{\circ} \mathrm{C}$ for 45 minutes. Afterward, membrane proteins including RIC-3 in the plasma membrane were solubilized in solubilization buffer (1.5\% Triton X-100, $100 \mathrm{mM} \mathrm{K}$-acetate, $40 \mathrm{mM} \mathrm{KCl,} 1 \mathrm{mM}$ EDTA, $10 \mathrm{mM}$ MOPS, $0.02 \%$ NaN3, 2 mM NEM; $p H$ 7.5) supplemented with the protease inhibitor cocktail III, $10 \mu$ protease per $1 \mathrm{ml}$ lysis buffer, at a ratio of $10 \mu \mathrm{l}$ buffer per oocyte. The solubilization was carried out for 2 hours at $4^{\circ} \mathrm{C}$ with gently mixing by inverting. After the solubilization was complete, the mixture was centrifuged at $30,000 \square \times \square g, 4^{\circ} \mathrm{C}$ for 1 hour. The supernatant was collected, quickly frozen in liquid nitrogen, and stored at $-80^{\circ} \mathrm{C}$ until use.

\section{Intracellular domain peptides of $5-\mathrm{HT}_{3}$ receptors}

L1-MX and MX peptides of the intracellular domain (ICD) from 5-HT 3 receptors, Fig. 2A, were designed to contain a C-terminal or N-terminal Cysteine (Cys) with a free sulfhydryl (-SH) group. The peptides were synthesized by GenScript or Biomatik and dissolved at a concentration of $2 \mathrm{mg} / \mathrm{ml}$ in ice-cold coupling buffer (50 mM Tris, $5 \mathrm{mM}$ EDTA-Na) or DMSO. Tris (2carboxyethyl) phosphine (TCEP) was added to the solubilized peptides at a final concentration of 2 to $2.5 \mathrm{mM}$ to prevent oxidation of sulfhydryl groups and maintain sulfhydryls. In case of L1MX L353A and MX peptides, ice-cold coupling buffer at $\mathrm{pH} 8.5$ and $\mathrm{pH} 9.5$, respectively, was 
used for initial dissolution; the $\mathrm{pH}$ of the peptide solutions was then adjusted to 8.35 and 9.02, respectively, to completely dissolve peptides completely.

Each peptide concentration was then determined using a nanodrop device (Nanodrop One ${ }^{\mathrm{C}}$, ThermoFisher Scientific) by measuring the absorbance at a wavelength of $280 \mathrm{~nm}$ or $205 \mathrm{~nm}^{56}$, and converted into the respective peptide concentration by using the peptide molecular weight, and peptide extinction coefficient using the following equation:

Peptide concentration $(\mathrm{mg} / \mathrm{ml})=($ Absorbance/Extinction coefficient $) \times$ Molecular weight.

\section{Pull-down assay of L1-MX peptides and RIC-3 Coupling of L1-MX peptides with iodoacetyl resin}

Thirty microliters of settled UltraLink ${ }^{\mathrm{TM}}$ iodoacetyl resin (ThermoFisher Scientific, \# 53155) were added to a Pierce spin column (Thermo Scientific, \#69705) and allowed to settle for 5 minutes at room temperature. The liquid was drained by spinning down at $1,000 \mathrm{~g}$ for 10 seconds. The resin was then washed three times with $300 \mu 1$ of coupling buffer $(50 \mathrm{mM}$ Tris, 5 mM EDTA-Na, pH 8.5). After removing the buffer of the third wash, peptide with a $\mathrm{N}$ - or Cterminal Cys was added to $30 \mu \mathrm{l}$ settled resin so that a ratio of resin-bound peptide/resin was between $1.72 \mathrm{mg} / \mathrm{ml}$ to $34 \mathrm{mg} / \mathrm{ml}$. This specific ratio was determined and optimized for each peptide. To determine the resin-bound peptide/resin ratio, L1-MX peptides were allowed to couple with iodoacetyl resin via a thioether bond between the sulfhydryl group of the peptide and the iodacetyl chains of the resin. The coupling reaction was conducted at room temperature for 2 to 5 hours depending on each peptide with gently inverting the spin columns for a few seconds every 30 minutes. Buffer containing unlinked peptide was removed from the spin column by spinning at 1,000 $\mathrm{g}$ for 10 seconds. The protein concentration in the flow-through was then determined with the NanoDrop One using the absorbance at $280 \mathrm{~nm}$ or $205 \mathrm{~nm}^{56}$, and peptide concentrations determined as described above. The unlinked peptide mass was calculated from the peptide concentration and the flow through volume. This mass represents unbound peptide and was subtracted with the peptide mass added to the spin column before the coupling reaction to obtain the resin-bound peptide mass. This mass was then divided by $30 \mu 1$ resin to obtain the ratio of resin-bound peptide/resin.

After the coupling, resin-bound peptides were washed with $300 \mu$ l of the coupling buffer, $\mathrm{pH} 8.5$ for 3 times, and available binding sites of resin were blocked using $120 \mu 1$ of freshly made 50 $\mathrm{mM}$ L-Cysteine containing $25 \mathrm{mM}$ TCEP, $\mathrm{pH}$ 8.5. For control pull-down samples, resin samples without coupled peptide were prepared similarly by modifying the iodoacetyl sidechains with Cys. The blocking reaction was conducted at room temperature with gently inverting spin columns for a few seconds every 10 minutes for 2 hours. The liquid was then removed by 
spinning at 1,000 $\mathrm{g}$ for 10 seconds, and the resin-bound peptide was washed separately with 600 $\mu 1$ of the coupling buffer, $600 \mu \mathrm{l}$ of $1 \mathrm{M} \mathrm{NaCl}$, and $600 \mu \mathrm{l}$ of storage PBS buffer $(0.1 \mathrm{M} \mathrm{Na}-$ phosphate, $0.15 \mathrm{M} \mathrm{NaCl}, 0.05 \% \mathrm{NaN}_{3}, \mathrm{pH} 7.2$ ). The peptide was then stored in the PBS buffer at $4^{\circ} \mathrm{C}$ until use.

\section{Pull-down assay with RIC-3}

Resin-bound peptides were prepared as described above with a minimum ratio of peptide/resin of $1.72 \mathrm{mg} / \mathrm{ml}$. Storage PBS buffer was removed from the peptides by spinning at 1,000 $\mathrm{g}$ for 10 seconds. The resin-bound peptides were then washed 3 times with $300 \mu 1$ of binding buffer

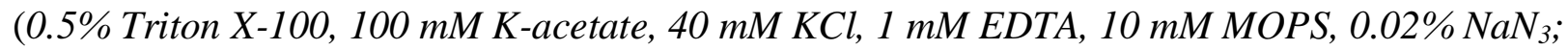
pH7.5). The binding buffer was removed by spinning at 1,000 $\mathrm{g}$ for 10 seconds. RIC-3 solubilized in $1.5 \%$ Triton X-100 was prepared as described above. The protein was thawed on ice for 20 minutes and then centrifuged at $30,000 \mathrm{~g}$ for 1 hour at $4^{\circ} \mathrm{C}$ before incubating with the peptide-resins. The supernatant was collected, and $40 \mu 1$ of this sample was added to $30 \mu \mathrm{l}$ of either resin alone or peptide-bound resin. The mixture was incubated at $4{ }^{\circ} \mathrm{C}$ for 2 hours. Afterward, $150 \mu \mathrm{l}$ of washing buffer 1 (1.2\% Triton X-100, $100 \mathrm{mM} \mathrm{K}$-acetate, $40 \mathrm{mM}$ $\mathrm{KCl}, 1 \mathrm{mM}$ EDTA, $10 \mathrm{mM}$ MOPS, 0.02\% NaN3; pH 7.5) was slowly applied to the wall of the spin column without disturbing the resin. The buffer was left in the column for 5 minutes before being removed at $1,000 \mathrm{~g}$ for 10 seconds at room temperature (RT). In the next step, $60 \mu 1$ of washing buffer 2 ( $1 M \mathrm{NaCl}, 25 \mathrm{mM}$ Tris-Cl, $1 \mathrm{mM} \mathrm{EDTA;} \mathrm{pH} 7.5$ ) was slowly applied to the wall of the spin column without disturbing the resin. The buffer 2 was drained by spinning at $1,000 \mathrm{~g}$ for 10 seconds at RT.

After washing, RIC-3 protein was eluted from resin-bound peptides by applying $40 \mu \mathrm{L}$ of the elution buffer (277.8 mM Tris- $\mathrm{HCl}, \mathrm{pH}$ 6.8, 44.4\% glycerol, $10 \%$ SDS, $10 \%$ 2-mercaptoethanol and $0.02 \%$ Bromophenol Blue) and incubating at $75^{\circ} \mathrm{C}$ for 5 minutes, before spinning down at $8,000 \mathrm{~g}$ for 3 minutes at RT. The flow through was analyzed using western blot /immunoblot as described below to detect the absence or presence of RIC-3.

\section{Immunoblot analysis}

The entire volume of each flow through obtained from the pull-down assay was separated on Mini-PROTEAN TGX gels (Bio-Rad) and proteins transferred to polyvinylidene fluoride (PVDF) membranes (Bio-Rad) using the Bio-Rad trans-blot turbo system following the manufacturer's protocol. PVDF membranes were briefly immersed in methanol and then equilibrated in western transfer buffer (20\% ethanol, $20 \%$ of Bio-Rad 5x transfer buffer, \#10026938) for 3-5 minutes. Proteins were then transferred to PVDF membranes at 2.5 Amperes and up 25 Volts for 4 minutes at room temperature. PVDF membranes were blocked under agitation in $5 \%$ nonfat milk in tween-containing tris-buffered saline buffer (TTBS buffer: $0.1 \%$ 
Tween-20, $100 \mathrm{mM}$ Tris, $0.9 \% \mathrm{NaCl}, \mathrm{pH} 7.5$ ) for one hour. Afterwards, the blot was incubated with RIC-3 primary/mouse antibody (Abnova Corporation, Cat \# H00079608-B01P) in a dilution of 1:2,000 overnight at $4^{\circ} \mathrm{C}$ with gentle shaking. Each blot was then washed 3 times, each for 5 minutes in TTBS before incubation with goat raised anti mouse secondary antibody, conjugated to horseradish peroxidase enzyme, HRP (ThermoFisher Scientific product \# 31430), in a dilution of 1:5,000 for two hours, under gentle agitation. Subsequently, the blot was washed five times, each for 5 minutes with $20 \mathrm{ml}$ of TTBS buffer. After an additional wash with tris-buffered saline (100 mM Tris, 0.9\% NaCl, pH 7.5), SuperSignal West Femto Maximum Sensitivity Substrate (Thermo Scientific) was used for visualizing RIC-3 signal with a digital imaging system (ChemiDoc MP, Bio-Rad).

\section{Electrophysiology - Xenopus laevis oocyte interaction assay}

Changes in the function of 5- $\mathrm{HT}_{3 \mathrm{~A}}$-wt receptor and Ala substitution constructs in the presence and absence of RIC-3 protein were probed using the two-electrode voltage-clamp (TEVC) technique three days post-injection of oocytes. TEVC data were acquired using a TEV-200A Voltage Clamp amplifier (Dagan Corporation), Digidata 1440A digitizer (Molecular Devices), and Clampex 10.7 with gap-free acquisition mode and $200 \mathrm{~Hz}$ sampling rate. Resistances of recording electrodes were in the range of 1-5 M $\Omega$. The ground electrode was made of $1 \%$ agarose in $3 \mathrm{M} \mathrm{KCl}$ and connected to a bath and a $200 \mu \mathrm{l}$ perfusion chamber containing Ringer's buffer or the OR2 buffer ( $82.5 \mathrm{mM} \mathrm{NaCl}, 1 \mathrm{mM} \mathrm{MgCl,} 20 \mathrm{mM} \mathrm{KCl,} 5 \mathrm{mM} \mathrm{HEPES}$; $\mathrm{pH}$ 7.5). The voltage and current electrodes were filled with $3 \mathrm{M} \mathrm{KCl}$ solution. Oocytes were voltage-clamped at a holding potential of $-60 \mathrm{mV}$ and continuously superfused under gravity application at 2-5 $\mathrm{ml} /$ minute. Currents of 5- $\mathrm{HT}_{3 \mathrm{~A}}$ receptors and engineered constructs expressed at the cell surface were evoked by applying $10 \mu \mathrm{M}$ serotonin creatinine sulfate complex (Sigma), or in short 5-HT, in OR2 buffer. Current amplitudes were obtained by subtracting the maximum current in the presence of 5-HT to the baseline or resting current in the absence of 5-HT. Currents recorded from oocytes injected with cRNA for both RIC-3 and 5- $\mathrm{HT}_{3 \mathrm{~A}}$ were recorded and analyzed similarly using Clampfit 10.7. Statistical significance was evaluated using GraphPad Prism 6 software.

\section{Results}

\section{The MX helix is essential for the physical interaction between RIC-3 and the $\mathbf{5 H T}_{3 \mathrm{~A}} \mathbf{I C D}$}

In previous studies, we have demonstrated that $\mathrm{RIC}-3$ directly interacts with the $5 \mathrm{HT}_{3 \mathrm{~A}}$ receptor, specifically its ICD, and that the interaction is physically mediated via the L1-MX fragment of 
the $\mathrm{ICD}^{50-52}$. In these prior studies, we used recombinant proteins fused with maltose-binding protein (MBP) to facilitate purification and increase stability of the fusion partners. Both MBPRIC-3 and MBP-5-HT $3 \mathrm{~A}$-ICD constructs in which segments of the ICD were sequentially deleted were expressed in E. coli and purified to homogeneity to explore protein-protein interaction. We demonstrated that the MBP-5-HT $3 \mathrm{~A}-\mathrm{L} 1-\mathrm{MX}$ construct was the smallest construct investigated to mediate RIC-3 interaction. Here, we aimed at investigating the interaction of the 24-amino acid long 5-HT $\mathrm{HA}_{3 \mathrm{~A}} \mathrm{~L} 1-\mathrm{MX}$ construct alone, without the highly-soluble and solubility enhancing MBPtag. To establish this modified system, we employed synthetic ICD peptides (Fig. 1A \& Fig $2 \mathrm{~A} \& \mathrm{~B}$ ) covalently linked to iodoacetyl resin and RIC-3 protein expressed in Xenopus laevis oocytes. The initial ICD peptides used were 5-HT 3 A-ICD-L1-MX with either a N- or C-terminal Cysteine (Cys). The Cys sulfhydryl was reacted with the iodoacetyl resin to form a stable thioether linkage. The peptide-resin was then used as the immobile phase together with solubilized RIC-3 protein in the mobile phase in a pull-down type assay. Non-covalently bound proteins were eluted with SDS-containing buffer, separated on SDS-PAGE and detected with RIC-3 antibody as described in detail in the method section. Representative data of RIC-3 expression in solubilized oocyte membranes and RIC-3 pull-down in eluates using resin without and with L1-MX peptide covalently bound are shown in Fig. 1C.

Without the injection of RIC-3 cRNA, no protein band was recognized by RIC-3 antibody in solubilized oocyte membrane samples (Fig. 2C). In contrast, a strong intensity band migrating just above $50 \mathrm{kDa}$ was detected in the lane containing a sample from solubilized membranes of oocytes injected with RIC-3 cRNA. The result was reproducible in at least three independent experiments using oocytes from three different batches. This result strongly indicates the presence of RIC-3 protein in the solubilized oocyte membranes. RIC-3 from three oocytes was then used for each pull-down assay reaction (Fig. 2C, rightmost lanes). Samples using resin unmodified with L1-MX peptide yielded a faint band indicative of weak/unspecific binding of RIC-3 to resin itself. In contrast, peptide-resin with L1-MX peptide at a peptide/resin ratio of $7.12 \mathrm{mg} / \mathrm{ml}$, showed a dramatically increased band intensity. The result was consistently observed in at least ten independent pull-down experiments, and the data from 4 experiments are shown in Fig. $2 \mathrm{C} \& \mathrm{D}$. We noticed that at a peptide/resin ratio is below $1.7 \mathrm{mg} / \mathrm{ml}$, it is challenging to distinguish the binding of RIC-3 to the peptide-resin from the baseline binding of RIC-3 to the resin. Therefore, we used peptide to resin ratios above $4 \mathrm{mg} / \mathrm{ml}$ for subsequent experiments when utilizing $30 \mu \mathrm{l}$ of settled resin to examine the interaction between RIC-3 and L1-MX peptides. We also noticed that more RIC-3 signal was detected when using higher peptide/resin ratios (Fig. 2D); however, we did not observe a linear relationship between detected RIC-3 signal and peptide/resin ratios using the pull-down assay. 
With the goal to more precisely define the interaction interface between RIC-3 and $5 \mathrm{HT}_{3 \mathrm{~A}}$ receptor, we then shortened the L1-MX peptide even further by removing the 6 amino acid long L1-segment (Fig. 2A). When using resin linked to the 17 amino acid MX-segment via an added N-terminal Cys for the RIC-3 pull-down, we obtained a much stronger band for RIC-3 as compared to the control sample with unlinked resin (Fig. 2E). The data are reproducible in at least eight independent experiments. We infer that the L1 fragment does not play a critical role in the interaction between RIC-3 and the $5 \mathrm{HT}_{3 \mathrm{~A}}-\mathrm{ICD}$. In other words, the MX fragment alone is sufficient for the RIC-3 and $5 \mathrm{HT}_{3 \mathrm{~A}}$-ICD interaction.

\section{Substitutions of Alanine residues at and between conserved sites, W347, R349, or L353 within the MX helix prevents the interaction of L1-MX with RIC-3}

To search for the RIC-3 binding interface within the 5-HT $\mathrm{HA}_{3 \mathrm{~A}} \mathrm{MX}$ segment, we used alanine scanning to generate single and multiple Ala replacements in the MX fragment (Fig. 3A). These Ala substituted peptides were then immobilized on iodoacetyl resin as described above and used to probe RIC-3 binding. Single Ala substitutions W347A, R349A, or L353A in the MX fragment gave rise to RIC-3 bands with a signal much stronger than that of the unspecific binding between resin and RIC-3. The W347A, R349A, or L353A peptides thus, individually, have little to no effect on the interaction between L1-MX and RIC-3 (Fig. 3B). However, the combined substitution of Ala residues for either seven amino acids from W347 to L353 (7A peptide, Fig. 3A) or three conserved positions W347, R349, and L353 (WRLAAA peptide, Fig. 3A) in the MX fragment drastically reduced the intensity of the RIC-3 bands to that of the unspecific or background binding between unmodified resin and RIC-3 (n=3). We infer that 7A and WRLAAA substitutions abolish the interaction with RIC-3 (Fig. 3C\&D). Our data suggest that conserved residues across species, W347, R349, and L353 in the MX fragment, together, play a critical role in the interaction between ICD and RIC-3.

To address how the Ala substitutions at these conserved positions affect the function of the 5$\mathrm{HT}_{3 \mathrm{~A}}$ receptor and the modulation of its functional surface expression by RIC-3, we introduced these substitutions, W347A, R349A, and L353A, in full-length 5- $\mathrm{HT}_{3 \mathrm{~A}}$ receptors and examined changes in the receptors' function using Xenopus oocytes and two-electrode voltage-clamp recordings.

\section{Functional roles of residues $\mathrm{W} 347, \mathrm{R349}$, and $\mathrm{L353}$ of $5-\mathrm{HT}_{3 \mathrm{~A}}$ receptor}

Using mutagenesis as described in the method section, we generated four constructs of $5-\mathrm{HT}_{3 \mathrm{~A}}$ receptors, i.e., three single Ala substitutions (W317A, R349A, or L353A) and one triple 


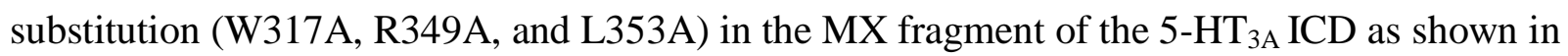
Figure 4A. Complementary RNA (cRNA) for these engineered constructs and the wild type 5$\mathrm{HT}_{3 \mathrm{~A}}$ receptor were injected into Xenopus oocytes, either alone or co-injected with cRNA of RIC-3. Three days post-injection, the oocytes were used to examine the effect of RIC-3 on the function of 5- $\mathrm{HT}_{3 \mathrm{~A}}$ channels by eliciting whole-cell currents with $10 \mu \mathrm{M}$ of serotonin (5-HT). At least six oocytes from two or three different batches of oocytes were utilized for each type of 5$\mathrm{HT}_{3 \mathrm{~A}}$ receptor.

As previously described ${ }^{40,47,52}$, we also observed that RIC-3 co-expression suppresses the wild type $5-\mathrm{HT}_{3 \mathrm{~A}}$ current amplitudes elicited by serotonin (Fig. 4A). The current recorded from wild type 5-HT HA $_{3}$ channels co-expressed with RIC-3 (WT + RIC-3) is almost completely abolished compared to the current elicited by only the wild type 5-HT $\mathrm{HA}_{3 \mathrm{~A}}$ channels (WT, Fig. 4A). Our data, therefore, reproduce the inhibitory effect of RIC-3 on the functional surface expression of 5$\mathrm{HT}_{3 \mathrm{~A}}$ channels in Xenopus oocytes. In addition, we also observed RIC-3 attenuated the current of 5- $\mathrm{HT}_{3 \mathrm{~A}}$ channels containing either point mutations or triple mutations (Fig. 4A).

In the absence of RIC-3 (Fig.4C), no significant differences in current amplitudes were observed between the wild type 5- $\mathrm{HT}_{3 \mathrm{~A}}$ channels (WT) and 5- $\mathrm{HT}_{3 \mathrm{~A}}$ channels with a single Ala substitution, W347A, R349A, or L353A. However, the current amplitude elicited from WRLAAA 5-HT 3 A channels was reduced to half compared to WT (One-way ANOVA with Tukey's posttest, $\mathrm{p} \leq$ 0.0001 ) or $5-\mathrm{HT}_{3 \mathrm{~A}}$ channels containing single Ala substitutions. In contrast, there were no significant differences in the current amplitudes invoked by WT and the single Ala substitutions. Our data suggests that single Ala substitutions W347A, R349A, or L353A do not interfere with the maximum current amplitude of the 5- $\mathrm{HT}_{3 \mathrm{~A}}$ channels, whereas the triple substitution W347A, R349A, and L353A significantly reduces current amplitudes compare to WT.

To further evaluate RIC-3's effect on the function of 5- $\mathrm{HT}_{3 \mathrm{~A}}$ receptors, we calculated a remaining current for each pair of 5- $\mathrm{HT}_{3 \mathrm{~A}}$ receptors as follows: remaining current $(\%)=$ the peak current amplitude of 5- $\mathrm{HT}_{3 \mathrm{~A}}$ channels in the presence of RIC-3 divided by the peak current amplitude from 5-HT 3 A channels alone. This remaining current reflects the effect of RIC-3 on the functional cell surface expression of $5-\mathrm{HT}_{3 \mathrm{~A}}$ channels; therefore, the remaining current can be used to assess the interaction between RIC-3 and 5-HT $\mathrm{HA}_{3 \mathrm{~A}}$ subunits of the receptor.

The remaining current of WRLAAA 5- $\mathrm{HT}_{3 \mathrm{~A}}$ channels is 2.2 times higher than that in wild type 5-HT $\mathrm{HA}_{3 \mathrm{~A}}$ channels (one-way ANOVA with Tukey's posttest, $\mathrm{p}<0.001$ ) (Fig. 4D). Our data thus suggest that triple mutations W347A, R349A, and L353A attenuate the inhibitory effect of RIC3 on the function of the 5- $\mathrm{HT}_{3 \mathrm{~A}}$ receptor. Similar effects of RIC-3 co-expression on the current amplitudes recorded from single Ala substitutions, W347A, R349A, or L353A, with p < 0.001, 0.05 , and 0.0001 , respectively. 


\section{Discussion}

Previously, we found that the interaction between 5- $\mathrm{HT}_{3 \mathrm{~A}}$ channels and RIC-3 chaperone requires the presence of the $5-\mathrm{HT}_{3 \mathrm{~A}}$ intracellular domain by using chimera constructs ${ }^{47,48,51}$. We then used recombinant 5-HT $3 \mathrm{~A}$ and RIC-3 proteins fused with maltose-binding protein (MBP-5$\mathrm{HT}_{3 \mathrm{~A}}$ and MBP-RIC-3) to demonstrate that the L1-MX fragment of the ICD is sufficient for the interaction with RIC-3 ${ }^{50,52}$. For the present work, we used synthetic L1-MX peptides and RIC-3 protein expressed in and extracted from Xenopus oocytes without fusion to MBP. We demonstrate the physical interaction between the L1-MX fragment of the ICD of the 5-HT $3 \mathrm{~A}$ subunit and RIC-3 protein also in this experimental setup (Fig. 2C\&D). Together, our data strongly prove that RIC-3 physically interacts with the intracellular domain of mouse 5- $\mathrm{HT}_{3 \mathrm{~A}}$ subunit regardless of experimental settings. We also showed that while the L1 fragment is not required, the MX fragment is sufficient for the protein-protein interaction with RIC-3 (Fig. 2E).

Interestingly, Hales and co-workers found that when most of the amino acids of the human 5$\mathrm{HT}_{3 \mathrm{~A}}$ receptor MX fragment were removed in their L-10(1) and L-10(2) constructs the functional surface expression of human $5-\mathrm{HT}_{3 \mathrm{~A}}$ receptor in HEK cells was abolished ${ }^{45}$.

Using a protein-protein pull-down assay, we further found that the combined Ala substitutions for three conserved residues, W347, R349, and L353, abolished the interaction of L1-MX peptide and RIC-3 (Fig. 3C). However, the single replacement with Ala at positions W347, R349, or L353 preserved this interaction (Fig. 3B). Our findings suggest that a group of amino acid residues governs the interaction between RIC-3 and the L1-MX peptide of the 5-HT $3 \mathrm{~A}$ receptor.

When these conserved residues were substituted by Ala residues in full-length $5-\mathrm{HT}_{3 \mathrm{~A}}$ receptors, we also observed a reduction in the functional expression as demonstrated by the current amplitude of the 5- $\mathrm{HT}_{3 \mathrm{~A}}$ construct containing triple mutations W347A, R349A, and L353A (Fig. 4). Without RIC-3, the current amplitude is reduced by half compared to the wild type (Fig. 4C). This result indicates a role of these residues in the function of the $5 \mathrm{HT}_{3 \mathrm{~A}}$ receptor. Our experiments cannot distinguish whether the effect is mediated via a reduction in surface expression itself or an impact on function (e.g. open probability, single-channel conductance). To our best knowledge, this is the first time the functional role of residues W347A, R349A, and L353A has been reported. Previous studies on the M3-M4 loop or ICD of 5-HT 3 A receptors or acetylcholine receptors from other groups did not specifically note the physiological role of W347, R349, and L353 residues ${ }^{23,29-32,45,57,58}$. 
The almost complete inhibition of serotonin-induced currents by RIC-3 co-expression in wildtype channels is significantly changed for all Ala substitution constructs. Single and triple substitutions alike lead to a $50 \%$ current reduction when RIC-3 is co-expressed, whereas in wildtype channels currents are reduced to $10 \%$. Our data here support the data above from the pull-down assay that removing triple residues W347, R349, and L353 disrupted the interaction between RIC-3 and 5-HT $\mathrm{H}_{3 \mathrm{~A}} \mathrm{~L} 1-\mathrm{MX}$. However, the disruption of the interaction observed from these two assays is not equivalent: the interaction was abolished seen via the pull-down assay versus the interaction was attenuated seen via the remaining current of two-electrode voltage clamp (TEVC) assay. Another difference is also observed for single Ala substitutions or point mutations at W347, R349, or L353: the interaction between L1-MX fragments and RIC-3 is observed via the pull-down assay versus the interaction between full-length $5-\mathrm{HT}_{3 \mathrm{~A}}$ receptors and RIC-3 was disrupted as shown via the remaining currents by TEVC assay (Fig. 4C, W347A vs. WT, R349A vs. WT, and L353A vs. WT).

The above differences in interactions of RIC-3 with either L1-MX mutants or full-length 5-HT $\mathrm{HA}_{3 \mathrm{~A}}$ mutants led us to question whether there is more than one binding site for RIC-3 on the $5-\mathrm{HT}_{3 \mathrm{~A}}$ subunit? When we searched for an amino acid sequence similar to MX, we found a cluster of residues in the transition between MA and M4 almost identical to the sequence on MX (Fig. 5B). W347 and R349 a part of the first half, a cluster of four residues, Glu, Trp, Leu, and Arg (or DWLR) found in both MX and MA-M4 fragments (Fig. 5B). Residue Leu353 belongs to the second cluster of four residues Val, Leu, Asp, and Arg (or VLDR), also found in the proximity of DWLR in the MA-M4 interface. Taken together, the duplicated clusters DWLR and VLDR in both the MX fragment and the MA-M4 transition, may indicate a second binding site for RIC-3 on the $5-\mathrm{HT}_{3 \mathrm{~A}}$ subunit.

A second binding site may explain the qualitative differences between the 5-HT 3 -peptide-RIC3-protein pulldown assay and the full-length 5-HT3A-RIC-3 functional assay. There would only be a single site in the MX-peptide, and the triple Ala substitution was able to completely prevent RIC-3 binding, as observed in the pull-down assay. In contrast, there would be two sites in the full-length 5-HT3A channel, so that the only partial effect of Ala substitutions (triple or single) in just one of the two sites on the RIC-3 inhibition can be explained.

\section{Conclusion}

Here we identify a sequence motif in $5-\mathrm{HT}_{3 \mathrm{~A}}$ channels within the intracellular domain $\mathrm{MX}$ fragment that mediates interaction with RIC-3. The motif is conserved across species and only observed in cation-conducting family members of pGLICs. Intriguingly, we observe a 
duplication of this binding motif for RIC-3 that is unique for the 5- $\mathrm{HT}_{3 \mathrm{~A}}$ receptor, but not other subunits. The identified key residues, tryptophan, arginine, and leucine, are represented in these two duplicated clusters in the MX fragment and at the MA-M4 interface of the ICD. Our findings provide detailed insights into the interaction between the intracellular domain of pGLICs and RIC-3 that can be used to guide drug design aiming at regulating the functional expression of pentameric neurotransmitter-gated ion channels.

\section{Supporting information}

This article does not contain supporting information

\section{Acknowledgments}

We thank the TTUHSC Core Facilities; some of the images and/or data were generated in the Image Analysis Core Facility and Molecular Biology Core Facility supported by TTUHSC.

\section{Author contributions}

Q.H.D. and M.J. conceived the project and designed the experimental procedures. Q.H.D. carried out all experiments, and data analysis. Q.H.D. and M.J. discussed data analysis and interpretation. Q.H.D. and M.J. wrote the paper.

\section{Funding and additional information}

Research reported in this publication was supported in part by the National Institute of Neurological Disorders and Stroke of the National Institutes of Health under award number R01/R56NS077114 (to M.J.). The funders had no role in study design, data collection and analysis, decision to publish, or preparation of the manuscript.

\section{Conflict of interest References}

1. Fakhfouri, G., Rahimian, R., Dyhrfjeld-Johnsen, J., Zirak, M. R. \& Beaulieu, J. M. 5-HT3 Receptor Antagonists in Neurologic and Neuropsychiatric Disorders: The Iceberg Still Lies beneath the Surface. Pharmacol Rev 71, 383-412 (2019).

2. Gibbs, E. \& Chakrapani, S. Structure, Function and Physiology of 5-Hydroxytryptamine Receptors Subtype 3. Subcell Biochem 96, 373-408 (2021).

3. Basak, S., Gicheru, Y., Rao, S., Sansom, M. S. P. \& Chakrapani, S. Cryo-EM reveals two distinct serotonin-bound conformations of full-length 5-HT3A receptor. Nature 563, 270-274 (2018). 
4. Polovinkin, L., Hassaine, G., Perot, J., Neumann, E., Jensen, A. A., Lefebvre, S. N., Corringer, P. J., Neyton, J., Chipot, C., Dehez, F., Schoehn, G. \& Nury, H. Conformational transitions of the serotonin 5-HT3 receptor. Nature 563, 275-279 (2018).

5. Derkach, V., Surprenant, A. \& North, R. A. 5-HT3 receptors are membrane ion channels. Nature 339, 706-709 (1989).

6. Reiser, G., Donie, F. \& Binmoller, F. J. Serotonin regulates cytosolic Ca2+ activity and membrane potential in a neuronal and in a glial cell line via 5-HT3 and 5-HT2 receptors by different mechanisms. J Cell Sci 93 ( Pt 3), 545-555 (1989).

7. Nichols, R. A. \& Mollard, P. Direct observation of serotonin 5-HT3 receptor-induced increases in calcium levels in individual brain nerve terminals. J Neurochem 67, 581-592 (1996).

8. Ronde, P. \& Nichols, R. A. High calcium permeability of serotonin 5-HT3 receptors on presynaptic nerve terminals from rat striatum. J Neurochem 70, 1094-1103 (1998).

9. Sugita, S., Shen, K. Z. \& North, R. A. 5-Hydroxytryptamine Is a Fast Excitatory Transmitter at 5Ht3 Receptors in Rat Amygdala. Neuron 8, 199-203 (1992).

10. McMahon, L. L. \& Kauer, J. A. Hippocampal interneurons are excited via serotonin-gated ion channels. J Neurophysiol 78, 2493-2502 (1997).

11. Humphrey, P. P., Bountra, C., Clayton, N. \& Kozlowski, K. Review article: the therapeutic potential of 5-HT3 receptor antagonists in the treatment of irritable bowel syndrome. Aliment Pharmacol Ther 13 Suppl 2, 31-38 (1999).

12. Spiller, R. C. Targeting the 5-HT(3) receptor in the treatment of irritable bowel syndrome. Curr Opin Pharmacol 11, 68-74 (2011).

13. Rubenstein, E. B. Palonosetron: a unique 5-HT3 receptor antagonist indicated for the prevention of acute and delayed chemotherapy-induced nausea and vomiting. Clin Adv Hematol Oncol 2, 284-289 (2004).

14. Herrstedt, J. \& Dombernowsky, P. Anti-emetic therapy in cancer chemotherapy: current status. Basic Clin Pharmacol Toxicol 101, 143-150 (2007).

15. Rojas, C. \& Slusher, B. S. Pharmacological mechanisms of 5-HT3 and tachykinin NK1 receptor antagonism to prevent chemotherapy-induced nausea and vomiting. Eur J Pharmacol 684, 1-7 (2012).

16. Kurhe, Y. V., Radhakrishnan, M., Thangaraj, D. \& Gupta, D. Anti-anxiety effect of a novel 5-HT3 receptor antagonist $\mathrm{N}$-(benzo[d] thiazol-2-yl)-3-ethoxyquinoxalin-2-carboxamide (6k) using battery tests for anxiety in mice. Indian J Pharmacol 46, 100-104 (2014).

17. Davies, P. A., Pistis, M., Hanna, M. C., Peters, J. A., Lambert, J. J., Hales, T. G. \& Kirkness, E. F. The 5-HT3B subunit is a major determinant of serotonin-receptor function. Nature 397, 359-363 (1999).

18. Lummis, S. C. R. 5-HT3 Receptors. Journal of Biological Chemistry 287, 40239-40245 (2012).

19. Dubin, A. E., Huvar, R., D'Andrea, M. R., Pyati, J., Zhu, J. Y., Joy, K. C., Wilson, S. J., Galindo, J. E., Glass, C. A., Luo, L., Jackson, M. R., Lovenberg, T. W. \& Erlander, M. G. The pharmacological and functional characteristics of the serotonin $5-\mathrm{HT}(3 \mathrm{~A})$ receptor are specifically modified by a 5 HT(3B) receptor subunit. J Biol Chem 274, 30799-30810 (1999).

20. Thompson, A. J., Lester, H. A. \& Lummis, S. C. The structural basis of function in Cys-loop receptors. Q Rev Biophys 43, 449-499 (2010).

21. Hassaine, G., Deluz, C., Grasso, L., Wyss, R., Tol, M. B., Hovius, R., Graff, A., Stahlberg, H., Tomizaki, T., Desmyter, A., Moreau, C., Li, X. D., Poitevin, F., Vogel, H. \& Nury, H. X-ray structure of the mouse serotonin 5-HT3 receptor. Nature 512, 276-281 (2014).

22. Basak, S., Gicheru, Y., Samanta, A., Molugu, S. K., Huang, W., la de Fuente, M., Hughes, T., Taylor, D. J., Nieman, M. T., Moiseenkova-Bell, V. \& Chakrapani, S. Cryo-EM structure of 5-HT3A

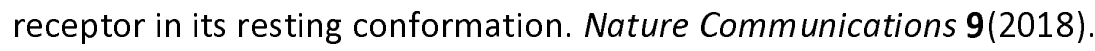


23. Kracun, S., Harkness, P. C., Gibb, A. J. \& Millar, N. S. Influence of the M3-M4 intracellular domain upon nicotinic acetylcholine receptor assembly, targeting and function. Br J Pharmacol 153, 1474-1484 (2008).

24. Bondarenko, V., Wells, M. M., Chen, Q., Tillman, T. S., Singewald, K., Lawless, M. J., Caporoso, J., Brandon, N., Coleman, J. A., Saxena, S., Lindahl, E., Xu, Y. \& Tang, P. Structures of highly flexible intracellular domain of human alpha7 nicotinic acetylcholine receptor. Nat Commun 13, 793 (2022).

25. Laverty, D., Desai, R., Uchanski, T., Masiulis, S., Stec, W. J., Malinauskas, T., Zivanov, J., Pardon, E., Steyaert, J., Miller, K. W. \& Aricescu, A. R. Cryo-EM structure of the human alpha1beta3gamma2 GABAA receptor in a lipid bilayer. Nature 565, 516-520 (2019).

26. Gharpure, A., Teng, J., Zhuang, Y., Noviello, C. M., Walsh, R. M., Jr., Cabuco, R., Howard, R. J., Zaveri, N. T., Lindahl, E. \& Hibbs, R. E. Agonist Selectivity and Ion Permeation in the alpha3beta4 Ganglionic Nicotinic Receptor. Neuron 104, 501-511 e506 (2019).

27. Morales-Perez, C. L., Noviello, C. M. \& Hibbs, R. E. X-ray structure of the human alpha4beta2 nicotinic receptor. Nature 538, 411-415 (2016).

28. Noviello, C. M., Gharpure, A., Mukhtasimova, N., Cabuco, R., Baxter, L., Borek, D., Sine, S. M. \& Hibbs, R. E. Structure and gating mechanism of the alpha7 nicotinic acetylcholine receptor. Cell 184, 2121-2134 e2113 (2021).

29. Kelley, S. P., Dunlop, J. I., Kirkness, E. F., Lambert, J. J. \& Peters, J. A. A cytoplasmic region determines single-channel conductance in 5-HT3 receptors. Nature 424, 321-324 (2003).

30. Hales, T. G., Dunlop, J. I., Deeb, T. Z., Carland, J. E., Kelley, S. P., Lambert, J. J. \& Peters, J. A. Common determinants of single channel conductance within the large cytoplasmic loop of 5hydroxytryptamine type 3 and alpha4beta2 nicotinic acetylcholine receptors. $J$ Biol Chem 281, 8062-8071 (2006).

31. Shen, X. M., Ohno, K., Sine, S. M. \& Engel, A. G. Subunit-specific contribution to agonist binding and channel gating revealed by inherited mutation in muscle acetylcholine receptor M3-M4 linker. Brain 128, 345-355 (2005).

32. Yu, X. M. \& Hall, Z. W. A sequence in the main cytoplasmic loop of the alpha subunit is required for assembly of mouse muscle nicotinic acetylcholine receptor. Neuron 13, 247-255 (1994).

33. Huebsch, K. A. \& Maimone, M. M. Rapsyn-mediated clustering of acetylcholine receptor subunits requires the major cytoplasmic loop of the receptor subunits. J Neurobiol 54, 486-501 (2003).

34. Jeanclos, E. M., Lin, L., Treuil, M. W., Rao, J., DeCoster, M. A. \& Anand, R. The chaperone protein 14-3-3eta interacts with the nicotinic acetylcholine receptor alpha 4 subunit. Evidence for a dynamic role in subunit stabilization. J Biol Chem 276, 28281-28290 (2001).

35. Halevi, S., McKay, J., Palfreyman, M., Yassin, L., Eshel, M., Jorgensen, E. \& Treinin, M. The Celegans ric-3 gene is required for maturation of nicotinic acetylcholine receptors. Embo Journal 21, 1012-1020 (2002).

36. Cheng, A. X., McDonald, N. A. \& Connolly, C. N. Cell surface expression of 5-hydroxytryptamine type 3 receptors is promoted by RIC-3. Journal of Biological Chemistry 280, 22502-22507 (2005).

37. Williams, M. E., Burton, B., Urrutia, A., Shcherbatko, A., Chavez-Noriega, L. E., Cohen, C. J. \& Aiyar, J. Ric-3 promotes functional expression of the nicotinic acetylcholine receptor alpha7 subunit in mammalian cells. J Biol Chem 280, 1257-1263 (2005).

38. Lansdell, S. J., Gee, V. J., Harkness, P. C., Doward, A. I., Baker, E. R., Gibb, A. J. \& Millar, N. S. RIC3 enhances functional expression of multiple nicotinic acetylcholine receptor subtypes in mammalian cells. Mol Pharmacol 68, 1431-1438 (2005).

39. Walstab, J., Hammer, C., Lasitschka, F., Moller, D., Connolly, C. N., Rappold, G., Bruss, M., Bonisch, H. \& Niesler, B. RIC-3 exclusively enhances the surface expression of human homomeric 
5-hydroxytryptamine type 3A (5-HT3A) receptors despite direct interactions with 5-HT3A, -C, -D, and -E subunits. J Biol Chem 285, 26956-26965 (2010).

40. Halevi, S., Yassin, L., Eshel, M., Sala, F., Sala, S., Criado, M. \& Treinin, M. Conservation within the RIC-3 gene family - Effectors of mammalian nicotinic acetylcholine receptor expression. Journal of Biological Chemistry 278, 34411-34417 (2003).

41. Miller, K. G., Alfonso, A., Nguyen, M., Crowell, J. A., Johnson, C. D. \& Rand, J. B. A genetic selection for Caenorhabditis elegans synaptic transmission mutants. Proc Natl Acad Sci U S A 93, 12593-12598 (1996).

42. Ben-David, Y., Mizrachi, T., Kagan, S., Krisher, T., Cohen, E., Brenner, T. \& Treinin, M. RIC-3 expression and splicing regulate nAChR functional expression. Mol Brain 9, 47 (2016).

43. Castillo, M., Mulet, J., Gutierrez, L. M., Ortiz, J. A., Castelan, F., Gerber, S., Sala, S., Sala, F. \& Criado, M. Dual role of the RIC-3 protein in trafficking of serotonin and nicotinic acetylcholine receptors. J Biol Chem 280, 27062-27068 (2005).

44. Biaggi-Labiosa, N. M., Aviles-Pagan, E., Caballero-Rivera, D., Baez-Pagan, C. A. \& LasaldeDominicci, J. A. Engineering alpha4beta2 nAChRs with reduced or increased nicotine sensitivity via selective disruption of consensus sites in the M3-M4 cytoplasmic loop of the alpha4 subunit. Neuropharmacology 99, 273-284 (2015).

45. Baptista-Hon, D. T., Deeb, T. Z., Lambert, J. J., Peters, J. A. \& Hales, T. G. The Minimum M3-M4 Loop Length of Neurotransmitter-activated Pentameric Receptors Is Critical for the Structural Integrity of Cytoplasmic Portals. Journal of Biological Chemistry 288, 21558-21568 (2013).

46. Papke, R. L. \& Horenstein, N. A. Therapeutic Targeting of alpha7 Nicotinic Acetylcholine Receptors. Pharmacol Rev 73, 1118-1149 (2021).

47. Jansen, M., Bali, M. \& Akabas, M. H. Modular design of Cys-loop ligand-gated ion channels: functional 5-HT3 and GABA rho1 receptors lacking the large cytoplasmic M3M4 loop. J Gen Physiol 131, 137-146 (2008).

48. Goyal, R., Salahudeen, A. A. \& Jansen, M. Engineering a prokaryotic Cys-loop receptor with a third functional domain. J Biol Chem 286, 34635-34642 (2011).

49. Mnatsakanyan, N., Nishtala, S. N., Pandhare, A., Fiori, M. C., Goyal, R., Pauwels, J. E., Navetta, A. F., Ahrorov, A. \& Jansen, M. Functional Chimeras of GLIC Obtained by Adding the Intracellular Domain of Anion- and Cation-Conducting Cys-Loop Receptors. Biochemistry 54, 2670-2682 (2015).

50. Nishtala, S. N., Mnatsakanyan, N., Pandhare, A., Leung, C. \& Jansen, M. Direct interaction of the resistance to inhibitors of cholinesterase type 3 protein with the serotonin receptor type $3 \mathrm{~A}$ intracellular domain. J Neurochem 137, 528-538 (2016).

51. Pandhare, A., Grozdanov, P. N. \& Jansen, M. Pentameric quaternary structure of the intracellular domain of serotonin type 3A receptors. Sci Rep 6, 23921 (2016).

52. Pirayesh, E., Stuebler, A. G., Pandhare, A. \& Jansen, M. Delineating the Site of Interaction of the 5-HT3A Receptor with the Chaperone Protein RIC-3. Biophys J 118, 934-943 (2020).

53. Dorr, P., Westby, M., Dobbs, S., Griffin, P., Irvine, B., Macartney, M., Mori, J., Rickett, G., SmithBurchnell, C., Napier, C., Webster, R., Armour, D., Price, D., Stammen, B., Wood, A. \& Perros, M. Maraviroc (UK-427,857), a potent, orally bioavailable, and selective small-molecule inhibitor of chemokine receptor CCR5 with broad-spectrum anti-human immunodeficiency virus type 1 activity. Antimicrob Agents Chemother 49, 4721-4732 (2005).

54. Antonia, S. J., Villegas, A., Daniel, D., Vicente, D., Murakami, S., Hui, R., Yokoi, T., Chiappori, A., Lee, K. H., de Wit, M., Cho, B. C., Bourhaba, M., Quantin, X., Tokito, T., Mekhail, T., Planchard, D., Kim, Y. C., Karapetis, C. S., Hiret, S., Ostoros, G., Kubota, K., Gray, J. E., Paz-Ares, L., de Castro Carpeno, J., Wadsworth, C., Melillo, G., Jiang, H., Huang, Y., Dennis, P. A., Ozguroglu, M. \& 
Investigators, P. Durvalumab after Chemoradiotherapy in Stage III Non-Small-Cell Lung Cancer. $N$ Engl J Med 377, 1919-1929 (2017).

55. Li, Q., Cheng, L., Shen, K., Jin, H., Li, H., Cheng, Y. \& Ma, X. Efficacy and Safety of Bcl-2 Inhibitor Venetoclax in Hematological Malignancy: A Systematic Review and Meta-Analysis of Clinical Trials. Front Pharmacol 10, 697 (2019).

56. Anthis, N. J. \& Clore, G. M. Sequence-specific determination of protein and peptide concentrations by absorbance at $205 \mathrm{~nm}$. Protein Sci 22, 851-858 (2013).

57. McKinnon, N. K., Reeves, D. C. \& Akabas, M. H. 5-HT3 receptor ion size selectivity is a property of the transmembrane channel, not the cytoplasmic vestibule portals. J Gen Physiol 138, 453-466 (2011).

58. McKinnon, N. K., Bali, M. \& Akabas, M. H. Length and Amino Acid Sequence of Peptides Substituted for the 5-HT3A Receptor M3M4 Loop May Affect Channel Expression and Desensitization. Plos One 7(2012). 

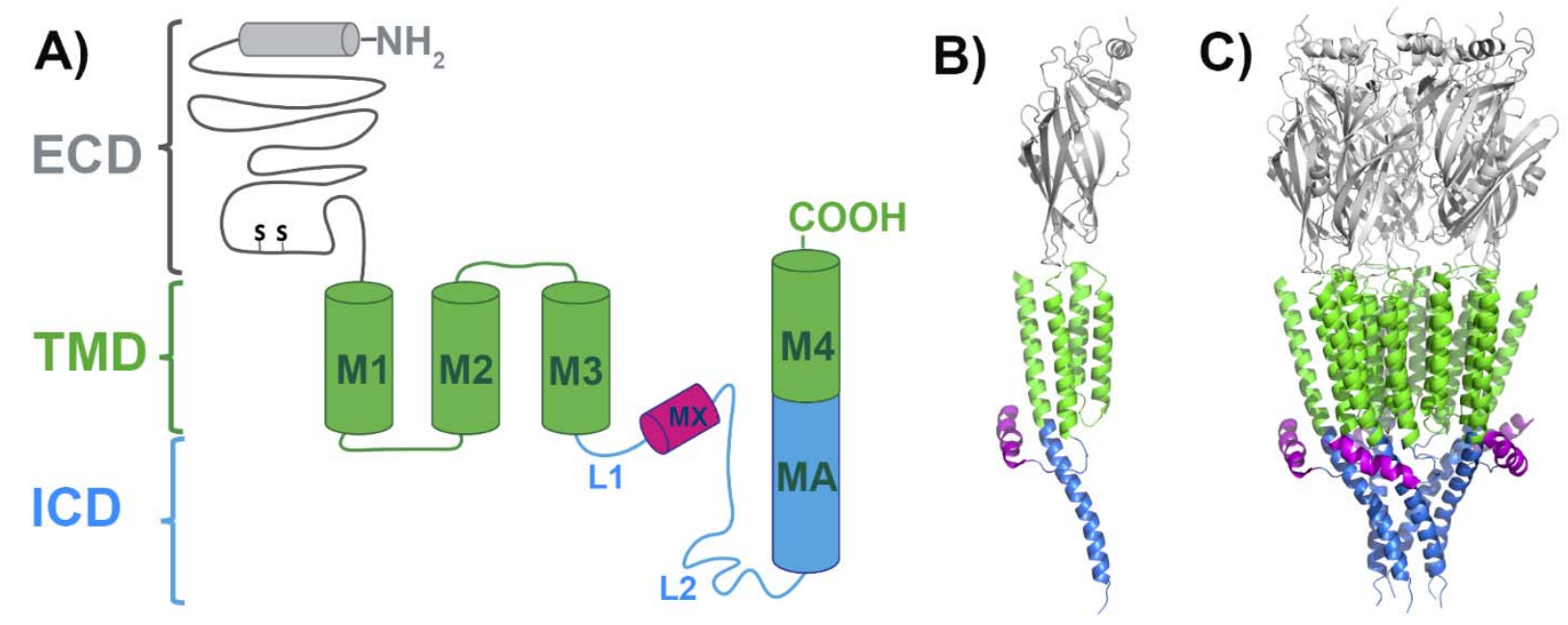

Figure 1. Schematic of 5-HT 3 A channel. A) Topology of a single subunit of serotonin type 3A receptor with domains color coded, extracellular (gray), transmembrane (green) with four $\alpha$ helical segments (M1 through M4), and intracellular (light blue and magenta) with a 17 amino acid long MX-helix and a membrane associated (MA) helix of 31 amino acids in length continuous with the subsequent M4 transmembrane helix. The L1-MX-segment has been shown to interact with RIC-3. B) and C) Single 5- $\mathrm{HT}_{3 \mathrm{~A}}$ subunit and pentameric 5- $\mathrm{HT}_{3 \mathrm{~A}}$ receptor (PDB ID: 4PIR). 


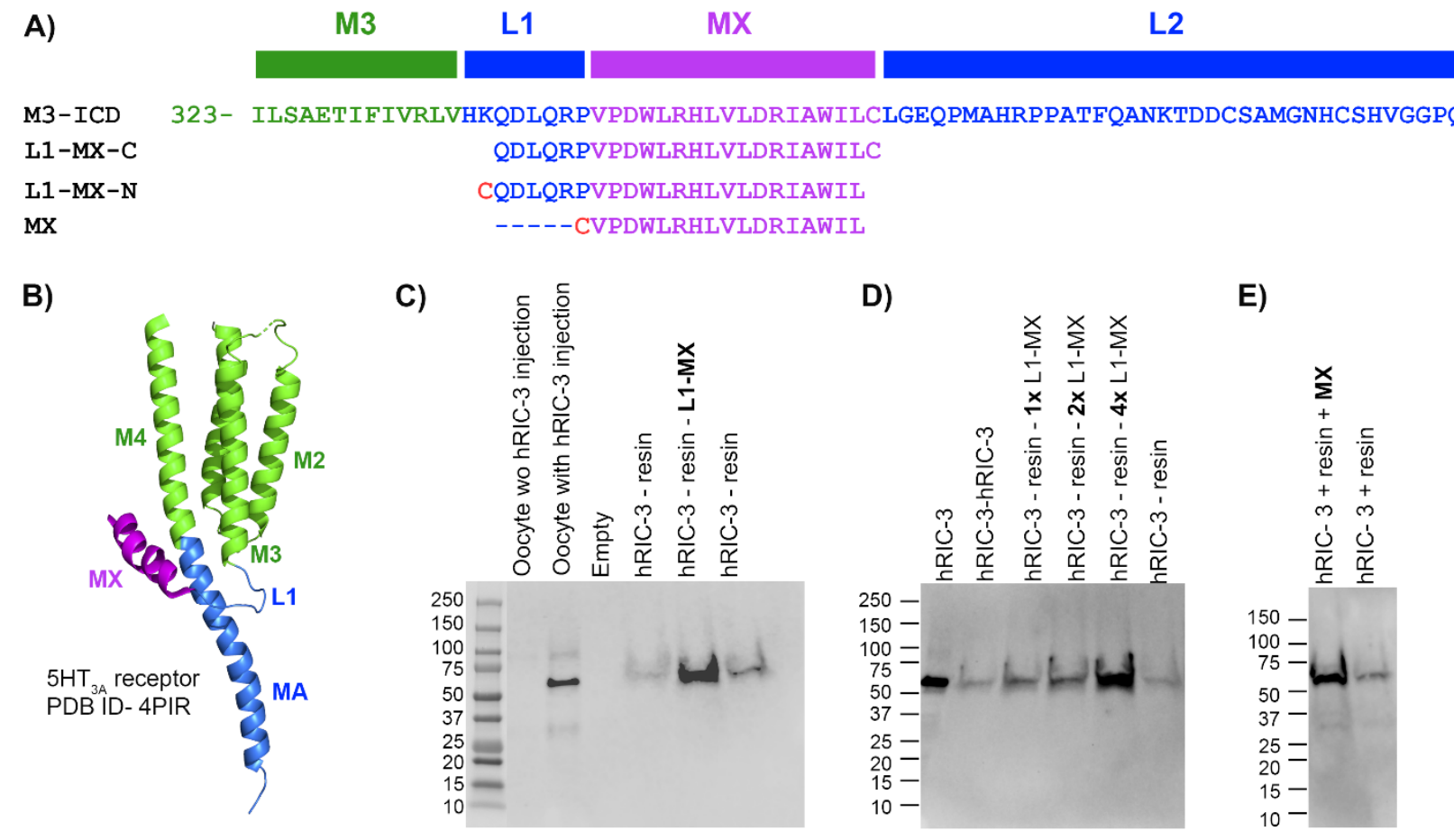

Figure 2. MX segment contains binding site for RIC-3. A) A 24-amino acid 5-HT 3 - $\mathrm{L} 1-\mathrm{MX}$ peptide as immobilized RIC-3 binding probe: The sequence context of the L1-MX-peptide is depicted starting with 13 amino acids near the end of M3 (green), continues with the L1-segment (blue), the MX-helix (magenta) and ends with a 36 residues of the long L2-loop (blue) that connects with the end of transmembrane segment M4 (MA -blue, not shown in A, only in B); and the alignment with the L1-MX-C (cysteine at C-terminus), L1-MX-N (cysteine at Nterminus), and MX peptides. B) Location of L1 and MX in the structure of a $5 \mathrm{HT}_{3 \mathrm{~A}}$ subunit (PDB ID: 4PIR). C) and D) Eluates of resin pull-downs of RIC-3. Western blot images show RIC-3 expressed in oocytes and control injection (water, wo). Eluates from resin alone show the presence of minor amounts of RIC-3, whereas eluates from resin covalently linked with L1-MX peptide show the presence of RIC-3. E) MX-fragment covalently linked to resin yields RIC-3 in pull-down eluates. $1 \mathrm{x}, 2 \mathrm{x}$, and $3 \mathrm{x}$ in panel $\mathrm{D}$ indicate increasing amounts of peptide linked to iodoacetyl resin. 


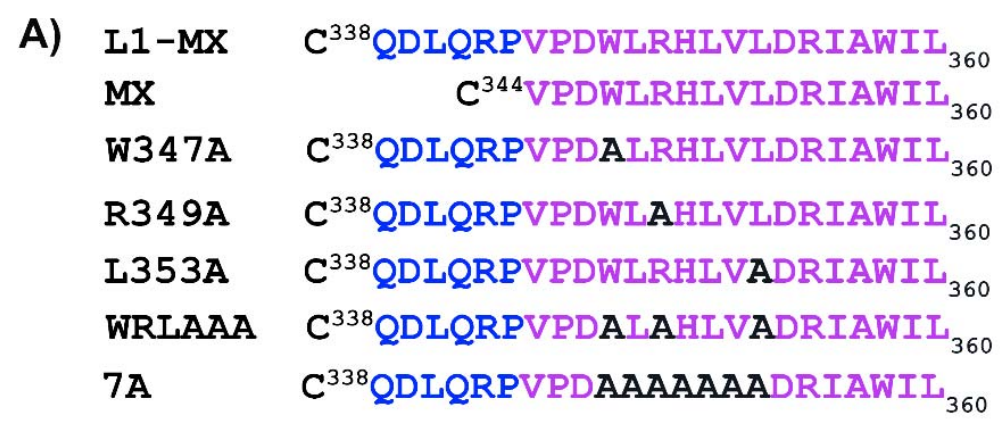

B)

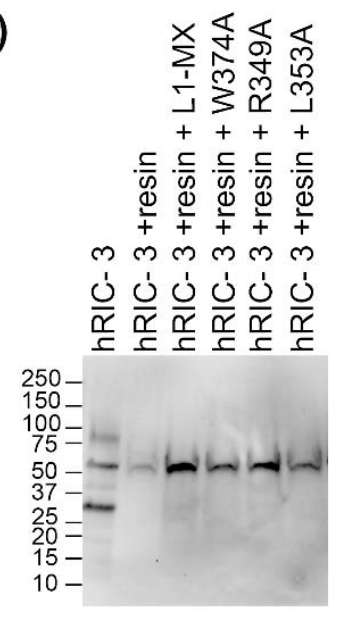

C)
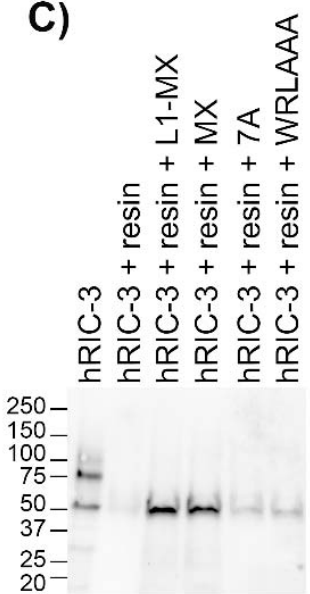

D)

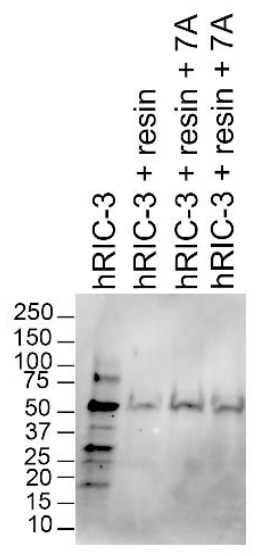

Figure 3. Effect of Alanine substitutions at conserved residues on RIC-3 interaction. A) Sequence of L1-MX and MX peptides, and single and multiple site substitution constructs W347A, R349A, L353A, WRLAAA, and 7A. B) Single site substitution constructs W347A, R349A, or L353A in the MX helix indicate preserved interaction with RIC-3, albeit with potentially altered affinity as based on the band intensity. C) and D) Constructs with multiple sites substituted, three sites substituted, W347, R349, and L353, together (WRLAAA), and seven sites substituted, W347 to L353 (7A), disrupt the interaction between L1-MX and RIC-3, yielding RIC-3 band intensities comparable to unmodified resin background. 

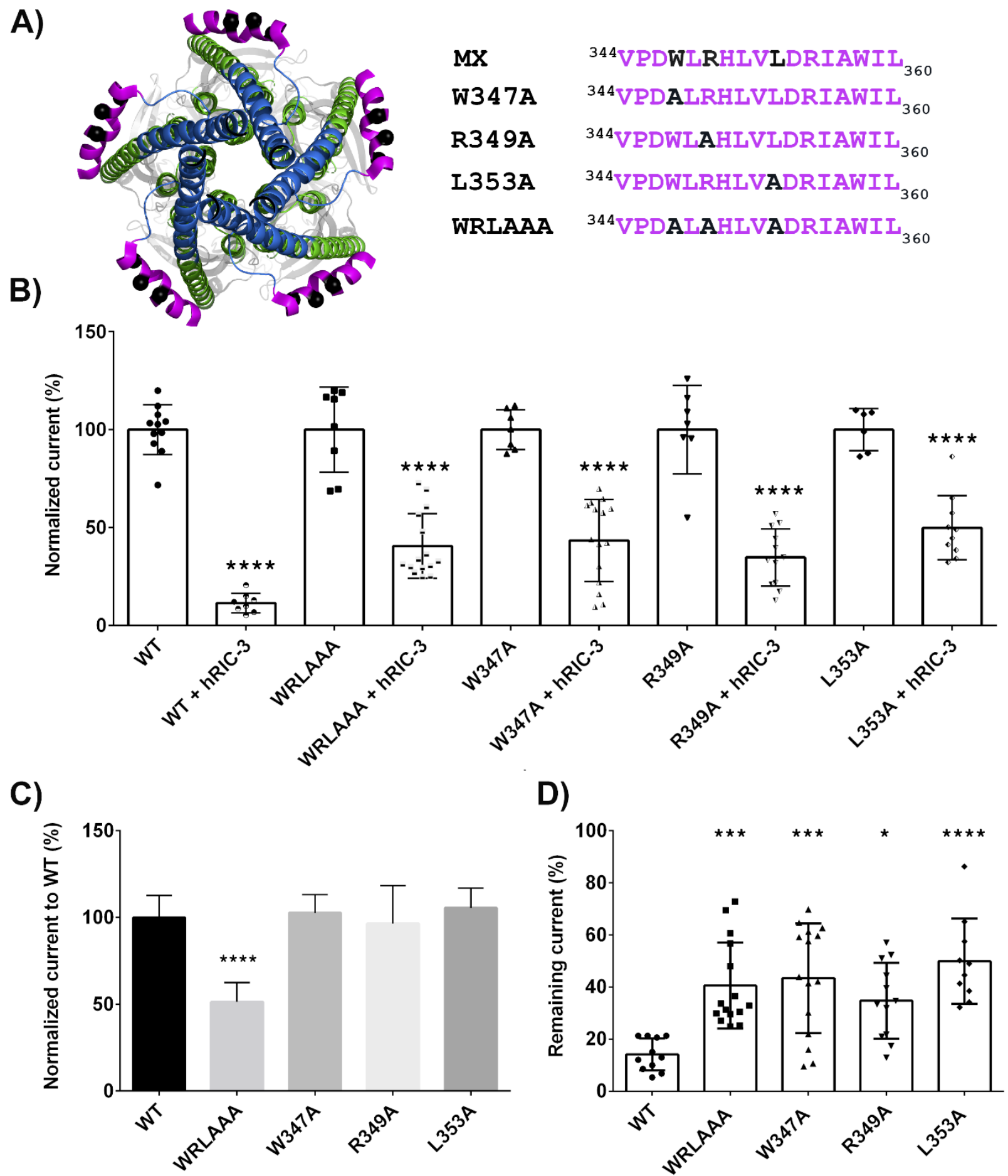

D)

Figure 4. Impact of Alanine substitutions on RIC-3 functional surface expression. A) View of 5$\mathrm{HT}_{3 \mathrm{~A}}$ channel (PDB ID: 4PIR) from the intracellular side perpendicular to the membrane, with residues W347, R349, or L353 in MX fragment highlighted in black; and the amino acid sequences of MX fragment, wild type and Ala substitutions. B) 5- $\mathrm{HT}_{3 \mathrm{~A}} \mathrm{R}$ normalized currents in the presence and absence of RIC-3. Data for each 5- $\mathrm{HT}_{3 \mathrm{~A}}$ construct pair (without and with RIC3 ) were normalized to the current amplitude obtained in the absence of RIC-3. Statistical 
significance was assessed for each pair. C) 5- $\mathrm{HT}_{3 \mathrm{~A}}$ normalized currents in the absence of RIC-3. Current amplitudes were normalized to the current amplitude of WT 5- $\mathrm{HT}_{3 \mathrm{~A}}$ receptor. Statistical significance was determined vs wildtype. D) Current for each construct in the presence of RIC-3 as in B. Statistical significance was determined vs. wildtype. Statistical significance was determined using one-way ANOVA with Tukey's multiple-comparisons test in Prism 6 software. Significance is indicated: $* \mathrm{p}<0.05, * * \mathrm{p} \leq 0.01, * * * \mathrm{p} \leq 0.001, * * * * \mathrm{p} \leq 0.0001$. 
A)

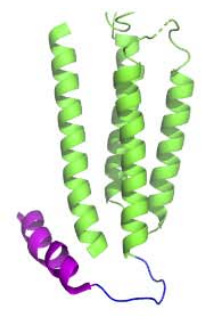

$5-\mathrm{HT}_{3 \mathrm{~A}}$

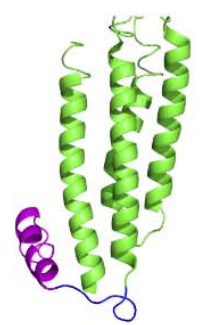

a3

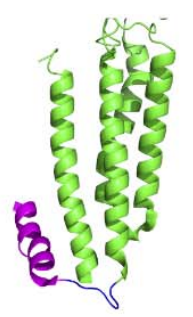

a4

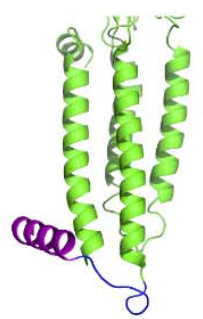

$\alpha 7$

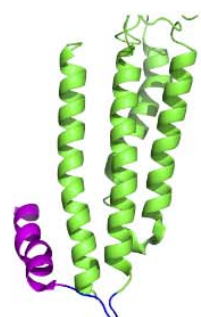

$\beta 2$

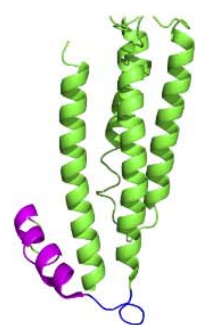

$\beta 4$
Q8K1F4|5-HT 3 A - mouse

P32297 | $\alpha 3-n A C h R-h u m a n$

P43681 | $\alpha 4-n A C h R-h u m a n$

Q05941| $\alpha 7-n A C h R-h u m a n$

P17787 | $\beta 2-n A C h R-h u m a n$

P30926 | $\beta$ 4-nAChR-human

P46098/5-HT ${ }_{3 A}$ - human

P04757 | $\alpha 3-n A C h R-r a t$

Q05941| $\alpha 7-$ nAChR-rat

P12390| $\beta 2-n A C h R-r a t$

P12392 | $\beta 4-n A C h R-r a t$

P09483| $\alpha 4-$ nAChR-rat

${ }^{33}$ QDLQRPVPDWLRHLVLDR IAWILC ${ }^{332}$ TPTTHTMP SWVKTVELNLLPRVMF ${ }^{334}$ SPRTHTMPTWVRRVFLDIVPRLLL ${ }^{321}$ DP DGGKMPKWTRVILLNWCAWELR ${ }^{325}$ SPTTHTMAPWVKVVFLEKLPALLF ${ }^{323}$ SPSTHTMAPWVKRCFLHKLPTFLF ${ }^{333}$ QDLQQPVPAWLRHLVLERIAWLLC ${ }^{326}$ TPTTHTMPTWVKAVFLNLLPRVMF ${ }^{321}$ DPDGGKMPKWTRI I LLNWCAWFLR ${ }^{324}$ SPTTHTMAPWVKVVELEKLPTLLF ${ }^{322}$ SPSTHTMASWVKECFLHKLPTFLF ${ }^{337}$ SPRTHTMPAWVRRVELDIVPRLLF * : $\quad$ *

B)

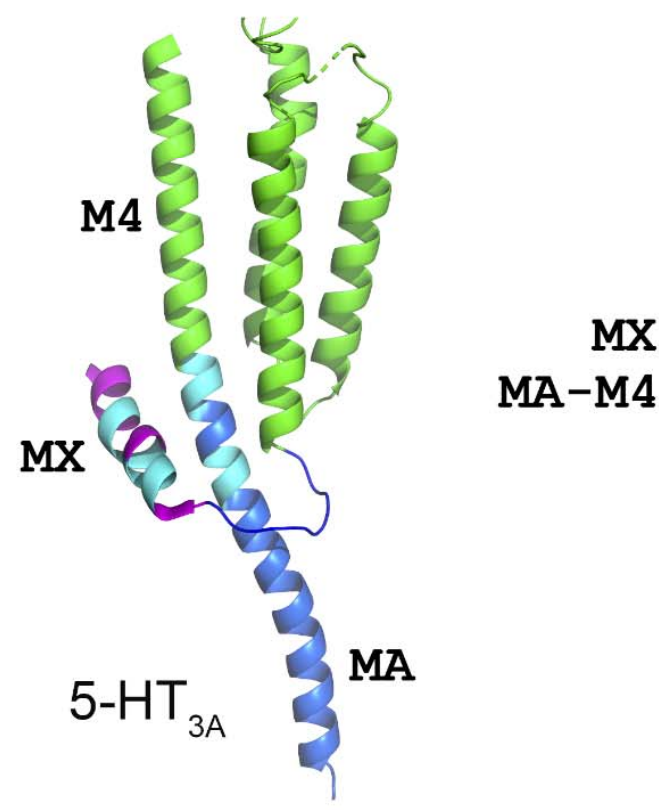

${ }^{344} \mathrm{VP}-\mathrm{DWL}$ RHL-VLDRIAWIL ${ }^{443}$ VARDWLRVGYVLDRLLF--

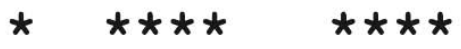

Figure 5. Sequence alignment. A) Upper panel: structural context and amino acid sequences of L1-MX peptides of $5 \mathrm{HT}_{3 \mathrm{~A}}$ and nACh subunits, $\alpha 3, \alpha 4, \alpha 7, \beta 2$, and $\beta 4$, with PDB IDs: 4PIR for 5- $\mathrm{HT}_{3 \mathrm{~A}}$ subunit, $6 \mathrm{PV} 7$ for $\alpha 3$ and $\beta 4$ subunits, $5 \mathrm{KXI}$ for $\alpha 4$ and $\beta 2$ subunits, and $7 \mathrm{KOO}$ for $\alpha 7$ subunit of nAChR. Lower panel: sequence alignment shows residues W347, R349, and L353 in 
L1-MX of 5- $\mathrm{HT}_{3 \mathrm{~A}}$ intracellular domain are conserved across species and subunits of cation conducting pentameric ligand-gated ion channels. B) Similarity of a motif in MX and at the interface of the MA-M4 helix of the 5- $\mathrm{HT}_{3 \mathrm{~A}}$ intracellular domain (PDB ID: 4PIR). Two amino acid clusters (cyan color) containing amino acids Glu, Trp, Leu, Arg (DWLR) and Val, Leu, Glu, Arg (VLDR) are present in both MX and MA-M4.
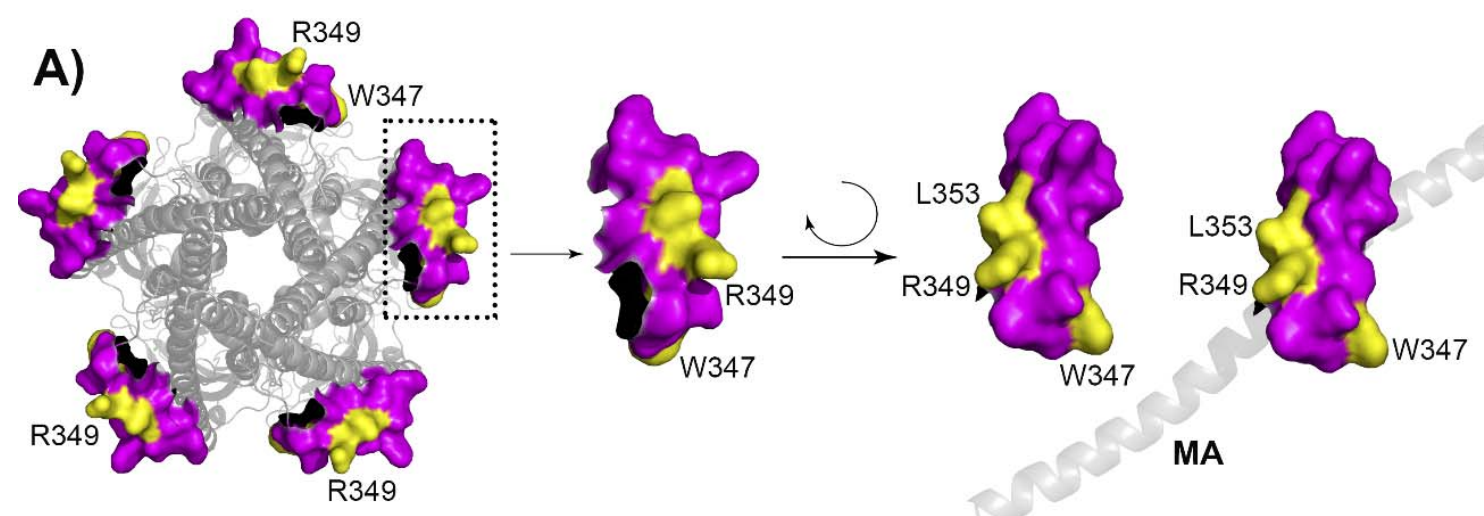

M4
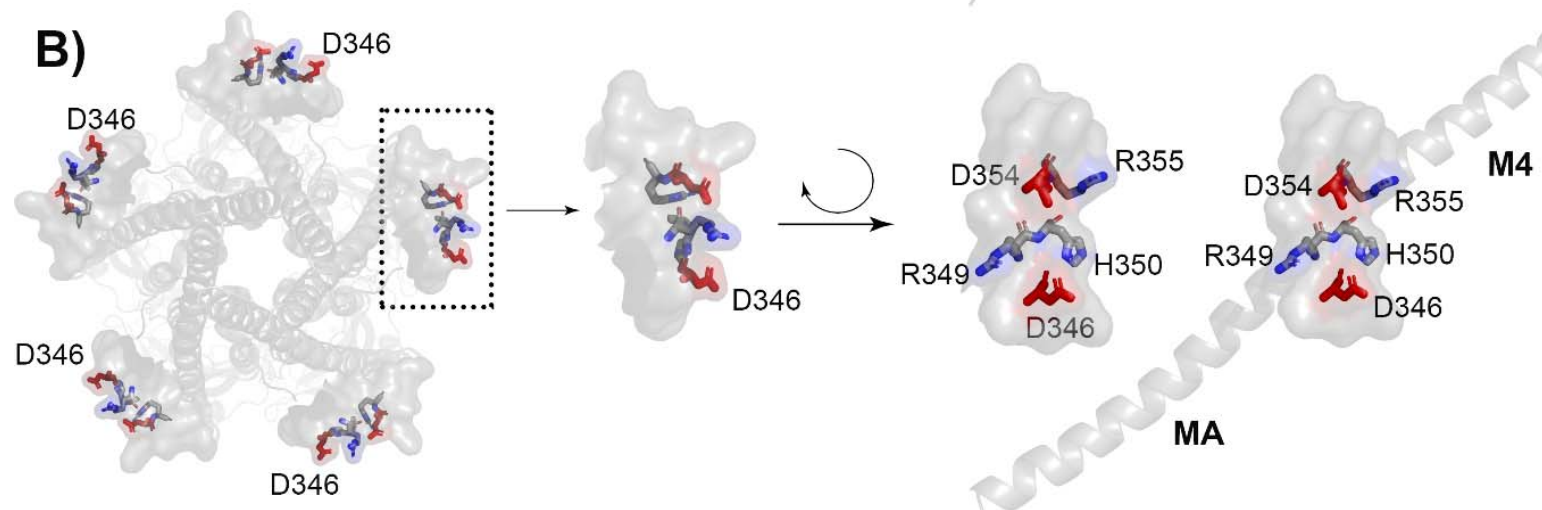

MA

Figure 6. MX fragment as a potential drug target. A) 5- $\mathrm{HT}_{3 \mathrm{~A}}$ receptor (PDB ID: 6W1J) as viewed from the intracellular side perpendicular to the membrane. MX-helix is in magenta space filling representation, and amino acids W347, R349, and L353 of MX are in yellow. B) MX is in light gray. Amino acids with charged side chains in stick representation with CPK colors (Nitrogen blue, Oxygen red). This illustration uses the cryoEM structure of 5- $\mathrm{HT}_{3 \mathrm{~A}}$ receptor $(\mathrm{PDB} 6 \mathrm{~W} 1 \mathrm{~J})^{1}$

1. Basak, S., Kumar, A., Ramsey, S., Gibbs, E., Kapoor, A., Filizola, M. \& Chakrapani, S. Highresolution structures of multiple 5-HT3AR-setron complexes reveal a novel mechanism of competitive inhibition. Elife $\mathbf{9}(2020)$. 